\title{
A SURVEY OF MARCHANTIALES FROM THE RUSSIAN FAR EAST III. NOTE ON MARCHANTIA PALEACEA BERTOL.
}

\section{ОБЗОР MARСНАNTIALES НА РОССИЙСКОМ ДАЛЬНЕМ ВОСТОКЕ III. ЗАМЕТКА О MARCHANTIA PALEACEA BERTOL.}

\author{
EUGENE A. BOROVICHEV ${ }^{1,2} \&$ VADIM A. BAKALIN 3,4 \\ ЕВГЕНИЙ А. БОРОВИЧЕВ ${ }^{1,2}$, ВАДИМ А. БАКАЛИН ${ }^{3,4}$
}

Abstract

\begin{abstract}
Marchantia paleacea Bertol. is a poorly known species in Russia not included into any regional handbook. The paper provides its morphological description and illustrations based on material from the Russian Far East, as well as the distinction from M. polymorpha L. s.l., the only other species known in Russia. M. paleacea subsp. paleacea is recorded for the first time in Primorsky Territory. Differentiation from M. paleacea subsp. diptera (Nees \& Mont.) Inoue is provided, the latter subspecies being a taxon which may be also found in the Russian Far East.
\end{abstract}

Резюме

\begin{abstract}
Marchantia paleacea Bertol. - малоизвестный в России таксон, не включенный в существующие отечественные определители. В статье приводятся морфологическое описание и иллюстрации на основе материала с территории Дальнего Востока России, отличия от второго известного в России вида (M. polymorpha L.). M. paleacea subsp. paleacea впервые приводится для Приморского края. Обсуждаются отличия типового подвида от другого, M. paleacea subsp. diptera (Nees \& Mont.) Inoue, который также может быть найден на российском Дальнем Востоке.
\end{abstract}

KEYWORDS: Marchantia paleacea, new records, Far East of Russia, taxonomy, Hepaticae

\section{INTRODUCTION}

The most common and widely known species of Marchantia in Russia is M. polymorpha L. Contrary, the second taxon of the genus, Marchantia paleacea Bertol., is much less known; it is disjunctively distributed in Russia (at least according to an available data). Marchantia paleacea is known in Asiatic Russia from the Caucasus, the Altai Mts. and Kunashir, the southern tip of Kurils Chain (Konstantinova, Bakalin \& al., 2009). In the course of the revision of Marchantiales in the Russian Far East we have revealed this unusual taxon in one locality from southernmost flank of the Primorsky Territory. The main goal of the present account is to attract an attention to Marchantia paleacea. The species may be found in some other localities both in the Russian Far East and in Russia as a whole. Since identification keys and descriptions of the species are absent in recent Russian literature, we provide the key and morphological description based on material from the Russian Far East.

KEY TO MARCHANTIA SPECIES KNOWN IN RUSSIA

1. Ventral scales in 6-8 rows by 3-4 on each side of the central midrib, extending on ventral side over 0.75 1.0 of thallus width and even beyond the margin; marginal ventral scales wider than long; dark band in the midline of dorsal surface may be present or absent; dorsal surface pores surrounded by $4-5$ superimposed cell rings; inner side of pore slightly narrowly cruciate M. polymorpha s.1.

- Ventral scales in 4 rows by two on each side of the central midrib, extending on ventral side up 0.3-0.6 of thallus width; marginal ventral scales longer than wide; dark band on thallus dorsal surface never present; pores surrounded by 5-8 superimposed cell rings; inner side of pore strongly narrowly cruciate M. paleacea

\footnotetext{
1 - Polar-Alpine Botanical Garden-Institute of the Kola Science Center of RAS, Kirovsk, Murmansk Province, 184256, Russia Россия, 184256, г. Кировск, Мурманская область, Полярно-альпийский ботанический сад-институт им. Н.А. Аврорина Кольского НЦ РАН;

2 - Institute of Industrial Ecology Problems of the North of the Kola Science Center of RAS, Apatity, Murmansk Province, 184209, Russia - Россия, 184209, г. Апатиты, Мурманская область, Институт проблем промышленной экологии Севера Кольского научного центра PAH e-mail: borovichyok@mail.ru;

3 - Botanical Garden-Institute FEB RAS, Makovskogo Street, 142, Vladivostok, 690024, Russia - Ботанический сад-институт ДВО РАН, ул. Маковского, 142, Владивосток, 690024;

4 - Institute of Biology and Soil Science FEB RAS, Stoletiya Vladivostoka Avenue, 159, Vladivostok, 690022, Russia, Биологопочвенный институт ДВО РАН, пр. Столетия Владивостока, 159, Владивосток, 690022; e-mail: v bak@list.ru
} 
Marchantia paleacea Bertol. Opusc. Sci. 1:242. 1817.

Thalli medium-sized, 5-8 mm wide, 15-30 mm long, forming small mats with other marchantioid liverworts, repeatedly dichotomously branched; segments oblong to ovate-oblong; apex emarginate; margin entire to crenulate, flat to undulate, frequently red-purplish to reddish pigmented along the border; upper surface without a dark median band, texture firm and rather leathery; color of upper surface pale-green to yellowish, sometimes with reddish tint. Dorsal epidermis uni- or bistratose; hyaline to rose; cells (30-)35-50 mm long, (18-)20-30 Mm wide, with thin to slightly thickened walls, with numerous pale oil-bodies; pores conspicuous, barrel-shaped, formed by 5-6(-7) superimposed concentric rings of 4-6 cells each with 2-3 rings of cells above the epidermis and up to 2-4 cells projecting under epidermal tissue into air-chamber space, inner opening with 4-5 cells, inner walls strongly protuberant, narrowly cross opening. Aerenchyma occupying 75-100 $\mathrm{mm}$ thick in the middle of thallus; air-chambers in one layer, composed by densely chlorophyllose filaments of 2-5 cells high, supplementary partitions absent; storage tissue occupying most of ventral part of thallus medially, decreasing laterally, along thallus midline ca. 20-30 cells high; central area frequently purple; cells parenchymatous. [Sclerotic cells and mucilage cavities absent in our material, although reported for the species by Schuster (1992) and BischlerCausse (1993)]. Midrib relatively well-defined, gradually passing into acute lamina; thallus in midline (650)750-800 Mm thick. Rhizoids smooth and pegged, densely covering ventral surface of midrib. Ventral scales purple, in 4 rows, by two on each side of the central midrib, overlapping, dimorphic: outer row scales distant, small, 0.5-1.2 mm long, and 0.4-0.8 mm wide; asymmetrically oblong to ovate-lingulate or elliptical, margin entire or with slime papillae, without appendage; inner row scales imbricate, asymmetrically triangular, up to $0.9 \mathrm{~mm}$ long and to $2 \mathrm{~mm}$ wide; gradually narrowed upward, abruptly and deeply constricted at appendage base, with up to 15 18 oil-cells scattered throughout; appendage ovate to cordate; marginally reddish or purplish to hyaline; margin entire or denticulate to crenulate; apex obtuse to acute; basally nearly cordate; appendage slightly projecting beyond margins at thallus apical point area. [Dioicous. Male and female receptacles stalked from an apical notch. Male receptacle stalk without band of air-chambers, with 2(-4) rhizoid furrows; receptacle usually 4.3-6.5 $\mathrm{mm}$ in diameter, nearly symmetrical, with 6-8 shallow, rounded lobes, dorsal side lacking papillae. Female receptacle stalk with 1 band of air-chambers and 2(-3) rhizoid furrows; receptacle usually 4.5-6.8 $\mathrm{mm}$ in diameter, nearly symmetrical to asymmetrical, with rounded median projection on dorsal side, deeply divided into (5-)7-11 lobes, convex and costate basally, hardly broadened apically. Stalks of male and female receptacles basally surrounded by large scales. Involucres hyaline or purplish at mar- gin, with ciliate lobes. Spores brown, 19-24(-28) Mm in diameter (Ladyzhenskaya, 1951; Bischler-Causse, 1989, 1993; Bischler \& Piippo, 1991; Bischler-Causse \& al., 2005; Singh \& Singh, 2009)]. Sterile plants are only known from the Russian Far East. Gemmae cups abundant, with margin laciniate-dentate and papillose on the outer surface; containing many gemmae; gemmae discoid, biconvex $0.2-0.3 \mathrm{~mm}$ in diameter.

Marchantia paleacea is easily distinguishable from M. polymorpha s.l. (Bischler, 1989) due to a combination of the following features: 1) absence of a dark median band on thallus dorsal surface; 2) inner side of pore strongly narrowly cross-shaped; 3 ) ventral scales in 2 rows on each side of midrib; 4) ventral scales dimorphic, with marginal elliptic, small and caducous, and with median ones imbricate, large, with cordate appendage projecting beyond margins at thallus apex; 5) median ventral scales appendages ovate to cordate, obtuse, acute or apiculate, purplish to hyaline with entire to crenulate margins.

Ecology. According to the data at hand, the species is basiphilous (at least facultatively), also resistant to arsenic (growing on travertine strata in Kunashir Island rich by calcium arsenate: Bakalin \& al., 2009). The studied gatherings from Kurils, Japan and Korea were taken from obvious $\mathrm{Ca}$-rich substrata, the only collection from Primorsky Territory was made from Miocene tufa. The species grows in open places (also in direct sunlight). It forms loose pure mats or rarely grows as an admixture to other thallose hepatics. There is no obvious restriction of the species to a particular vegetation type. Within the Russian Far East, Korea and, partly, adjacent erritories of Japan, it grows in temperate broad-leaved forest belt at rather low altitudes.

Distribution: According to H. Bischler (Bischler, 1989; Bischler-Causse, 1993), the taxon has a circumtethyan distribution. It is known from North, Central and South America, Azores Islands; in Europe it is common in the Mediterranean region, northward to $45^{\circ} \mathrm{N}$; northern Africa; northern Yemen, India, Bhutan, Nepal, Pakistan, Indonesia China, Japan, Korea and Malaysia (Bischler, 1989; Piippo, 1990; Schuster, 1992; BischlerCausse 1993; Yamada \& Choe, 1997; Bapna, Kachroo, 2000; Bischler-Causse \& al., 2005; Yamada \& Iwatsuki, 2006; Singh \& Singh, 2009; Piippo, Koponen, 2013). Outside the general range, it occurs (although without gametangiophores) also in Ethiopia and Reunion (Bischler-Causse, 1993).

In the areas adjacent to the South of the Russian Far East, the species is known from Jilin Province ofChina, (Piippo, 1990) and from Hokkaido Prefecture in Japan (Yamada \& Iwatzuki, 2006). The nearest collection which we checked was from Oshima subprefecture of Hokkaido (Hepaticae Japonicae Exsiccatae, 783, see specimens examined). Within Russia, it was reported from the Caucasus (Krasnodar Territory: Konstantinova \& Savchenko, 

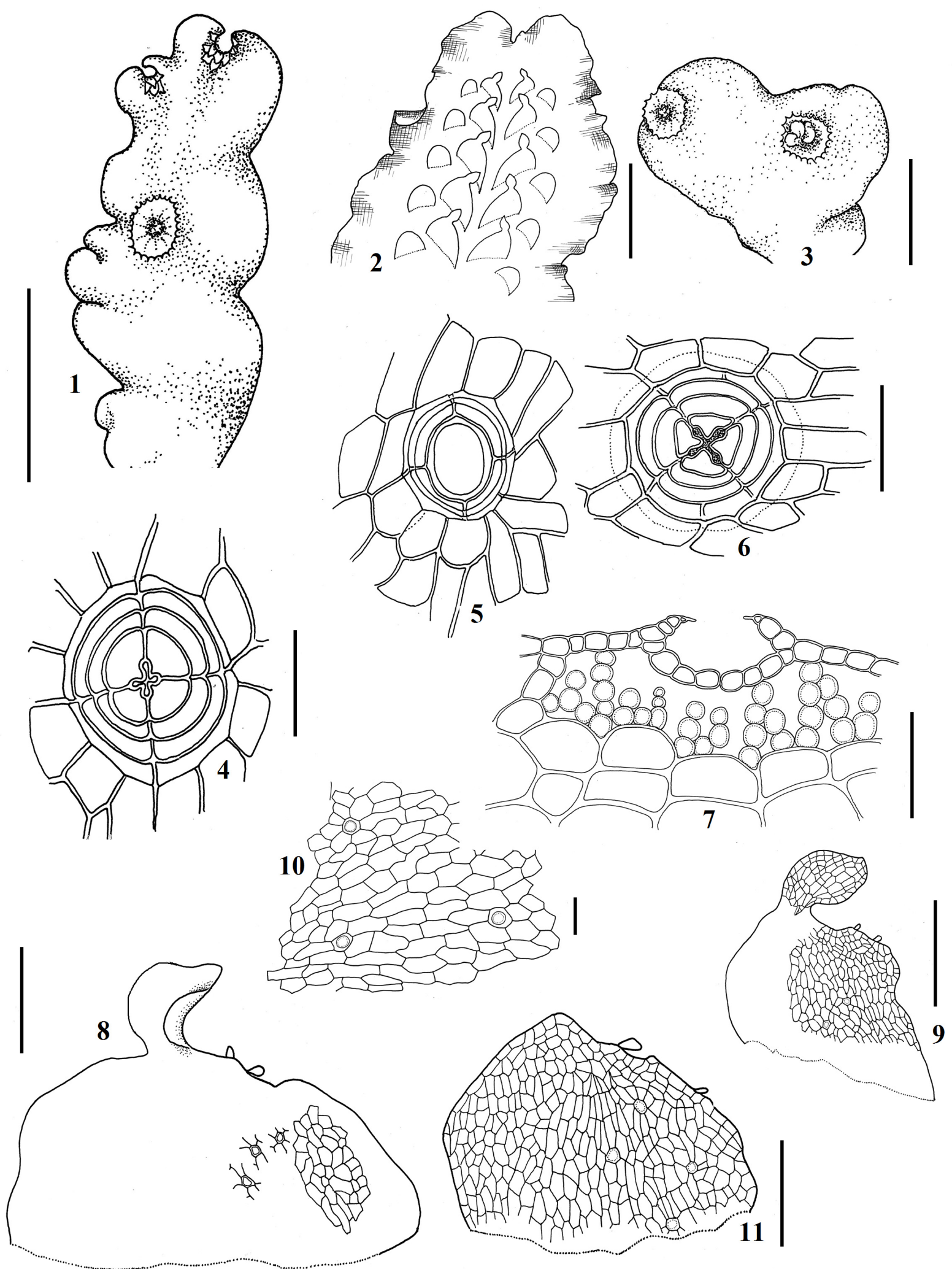

Fig. 1. Marchantia paleacea Bertol. 1,3 - habit of sterile plants with gemmae cups, dorsal view; 2 - habit of sterile plants, ventral view; 4-6 - air-pores from dorsal epidermis of thallus; 7 - part of transverse section with air-pore; 8-9 - median ventral scales with appendages; 10 - part of median ventral scales with oil-cells; 11 - laminar ventral scale. Scale bars: $10 \mathrm{~mm}$ for $1 ; 5 \mathrm{~mm}$ for $3 ; 3 \mathrm{~mm}$ for $2 ; 700 \mu \mathrm{m}$ for $9 ; 500 \mu \mathrm{m}$ for $8 ; 300 \mu \mathrm{m}$ for $11 ; 100 \mu \mathrm{m}$ for $7 ; 35 \mu \mathrm{m}$ for $4-6,10$. All from Primorsky Territory, 20.IX.2010 Bakalin \#P46-1-10 (VBGI). 
2009), South Siberia (Republic of Altai: Vбca \& Ignatov, 1995 ) and the Russian Far East (Kunashir Island: Bakalin \& al., 2009). We found this species also in the continental part of the Russian Far East, Primorsky Territory (see specimens examined). Taking into account the general distribution range, as well as ecological preferences of the species, we suggest that $M$. paleacea may be found in some other localities of the Russian Far East, particularly in its southern part. However, any suggestions in this respect seem to be very speculative, at least after checking of ca. 50 specimens collected in the southern part of the Russian Far East and identified as M. polymorpha in VBGI, we were not able to find $M$. paleacea.

The specimens from the Russian Far East fall into $M$. paleacea ssp. paleacea. In addition, one more subspecies (M. p. ssp. diptera (Nees \& Mont.) H. Inoue) may be found in the Russian Far East. Both subspecies differ in following characters: 1) appendage of inner row scales acute or apiculate, rarely obtuse to rounded in subsp. paleacea whereas subsp. diptera has rounded, rarely obtuse appendages; 2) subsp. paleacea is characterized by pores usually surrounded by 5-6 superimposed cells rings versus pores usually surrounded by 7-8 superimposed cells rings of subsp. diptera. The subspecies is currently known only from Korea (Yamada \& Choe, 1997), Japan (Yamada \& Iwatsuki, 2006) and China (Yunnan, Guangdong, Zheijang and Taiwan Provinces: Piippo, 1990). Therefore, based on the total distribution, we can expect that in the course of further studies M. paleacea subsp. diptera may be also found in the Russian Far East.

Selected specimens examined: Marchantia paleacea Bertol.: RUSSIA: Sakhalin Province, Kurils Chain, Kunashir Is-

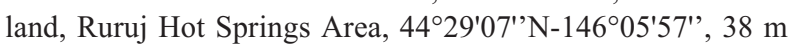
alt., destroying travertine cone, in percolated thermal water, 27.VIII.2007, Bakalin \#\# K36-1-06, K36-2-06 (VBGI, KPABG); Primorsky Territory, Khasansky District, Kravtsovka Village,

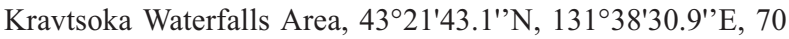
$\mathrm{m}$ alt., wet tufa cliffs near waterfalls, with gemmae, in mixture with Conocephalum salebrosum Szweik., Buczk., Odrzyk., 20.IX.2010, Bakalin \#P 46-1-10 (VBGI); JAPAN. Hokkaido Prefecture, Oshima Subprefecture, ca. $42^{\circ} 30^{\prime} \mathrm{N}-140^{\circ} 22^{\prime} \mathrm{E}, 200$ $\mathrm{m}$ alt., on soil in limestone area, 5.XI.1967 Sasaki T. (Hepaticae Japonicae Exsiccatae, Ser. 16. (1969) No. 783, SAPS). Marchantia paleacea subsp. diptera (Nees \& Mont.) Inoue: SOUTH KOREA. Ganqwon-do, Yeongwol-gun, Yeongwol-

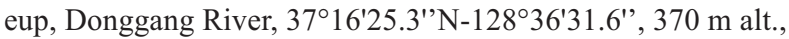
on shaded limestone covered thin soil near the river, 29.IX.2009, Choi \#5244 (VBGI).
ACKNOWLEDGEMENTS.

The figure for the present paper was provided by $\mathrm{Mr}$. M.A. Bakalin to whom authors are sincerely grateful. We are cordially thanking Dr. M.S. Ignatov for helpful comments on the manuscript. Authors also thank Prof. H. Takahashi for a kind permission to work in herbarium SAPS. The work was partially supported by the RBR (grants no. 12-04-01476, 13-04-00775); the work of V.A. Bakalin was also supported by the Hokkaido University Museum (Japan) as the part of visiting professor program.

\section{LITERATURE CITED}

BAKALIN V.A., V.YA. CHERDANTSEVA, M.S. IGNATOV, E.A. IGNATOVA \& T.I. NYUSHKO 2009. Bryophyte flora of the South Kuril Islands (East Asia). - Arctoa 18: 69-114.

BAPNA, K.R. \& P. KACHROO 2000. Hepaticology in India-II. Udaipur-New Delhi: 1-491.

BISCHLER-CAUSSE, H. 1989. Marchantia L. The Asiatic and Oceanic taxa. - Bryophyt. Biblioth. 38: 1-317.

BISCHLER-CAUSSE, H. 1993. Marchantia L. The European and African taxa. - Bryophyt. Biblioth. 45: 1-129.

BISCHLER-CAUSSE, H., R.S. GRADSTEIN, S. JOVET-AST, D.G. LONG \& N.S. ALLEN 2005. Marchantiidae. - Flora Neotropica Monograph 97: 1-270.

BISCHLER, H. \& S. PIIPPO 1991. Bryophyte flora of the Huon Peninsula, Papua New Guinea. L. Marchantia (Marchantiaceae, Hepaticae). Ann. Bot. Fenn. 28: 277-301.

KONSTANTINOVA, N.A., V.A. BAKALIN, E.N. ANDREJEVA, A.G. BEZGODOV, E.A. BOROVICHEV, M.V. DULIN \& YU.S. MAMONTOV 2009. Check-list of liverworts (Marchantiophyta) of Russia. - Arctoa 18: 1-63.

KONSTANTINOVA, N.A. \& A.N. SAVCHENKO 2009. New liverwort records from Krasnodar Territory. - Arctoa 18: 261-262.

PIIPPO, S. 1990. Annotated catalogue of Chinese Hepaticae and Anthocerotae. - J. Hattori Bot. Lab. 68: 1-192.

PIIPPO, S. \& T. KOPONEN 2013. Bryophyte flora of Hunan Province, China. 16. Complex thalloids (Marchantiopsida, Hepaticae). - Polish Bot. J. 58(1): 179-192.

SCHUSTER, R.M. 1992. The Hepaticae and Anthocerotae of North America east of the hundredth meridian. Chicago, 6: 1-937.

SINGH, S.K. \& D.K. SINGH 2009. Hepaticae and Anthocerotae of Great Himalayan National Park (HP), India. Botanical Survey of India, Kolkata: $1-465$.

VÁŃA, J. \& M.S. IGNATOV 1995. Bryophytes of Altai Mountains. Preliminary list of Altaian hepatics. - Arctoa 5: 1-14.

YAMADA, K. \& D.-M. CHOE 1997. A checklist of Hepaticae and Anthocerotae in the Korean Peninsula. - J. Hattori Bot. Lab. 81: 281306.

YAMADA, K. \& Z. IWATSUKI 2006. Catalog of the hepatics of Japan. J. Hattori Bot. Lab. 99: 1-106. 